Egyptian J. Anim. Prod., 41, Suppl. Issue, Nov. (2004):377-378

\title{
EFFECT OF AGE ON SEMEN TRAITS AT AWASS SHEEP
}

\author{
Y. Al-Bakkour
}

Department of Animal Production, Faculty of Agriculture Aleppo- University, Syria

\section{SUMMARY}

The research was conducted on (20) rams ofAwass sheep in special, near Hama City to estimate semen efficiency and spermatozoon characters in the ewes mating and to study the using possibility of (A. I) technique in sheep. The age of rams ranged between 2-6 years. And they maintaied in the same conditions of nutrition, raring and supplying. The semen had gotten by electric charge in the ram rectum with slight electric density (10) volt and frequented every $5 \mathrm{sec}$. The semen was gotten 6 times during 3 monthes, twice per month. Quantity, color and PH of semen were studies. Number of soermatozoon, defected shaps, total mobility fore and ranged mobility were studies also.

The results pointed out that the color of semen ranged between cream-yallow, watery and milky. Quantity of semen dose not exceeded (2) cm3, in the filurther good sample. There are no statistical differences between rams, having various ages in the semen quantity. $\mathrm{pH}$ of semen ranged between 7.5-8. Age of rams had no any influence on this character. Number of spermatozoons in semen ranged between 0.35. 0.67.109. May this range in spermatozzon numbers attributed to the various genotypes, physiological characters and fertile conditions.

Mobility types of spermatozoonz was good and it indicated to good efficiency in semen. Noted also that, some samples had few numbers in fore mobility.

Keywords: Awass sheep, age, semen traits 
تأثير العمر على صفات السائل المنوى فى كباش العواس يوسف البكور

قسم الإتتاج الحيوانس، كلية النراعة، جامعة حب، سوريا

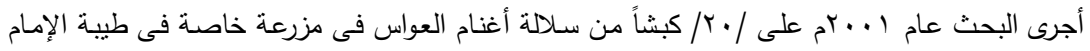

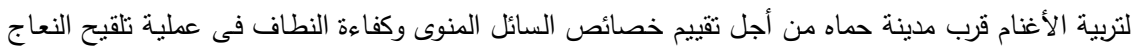

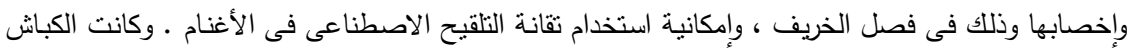

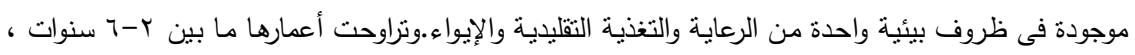

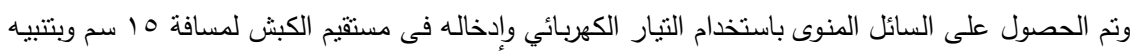

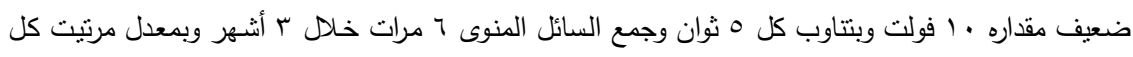
شهر. وقد درس فى السائل المنوى خصائص الحجم واللون ودرجة الـ PH وحركة النطاف الإجمالية والتموج والحركة التقدمية الأمامية والتذبذبية وعدد النطاف والأثكال الثاذة أيضاً.

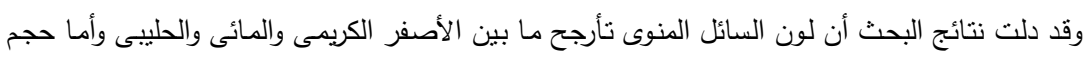

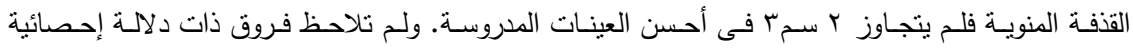

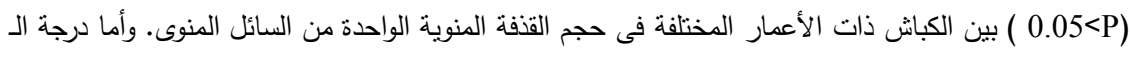

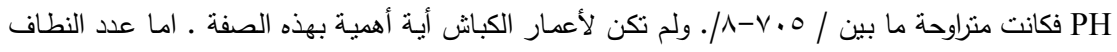

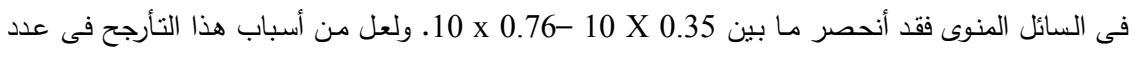
النطاف اختلاف التزكيب الوراثى للكباش وتباين الحالة الصحية والفيزيولوجية وغيرها.

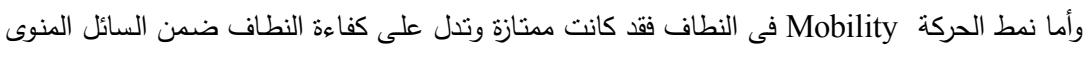

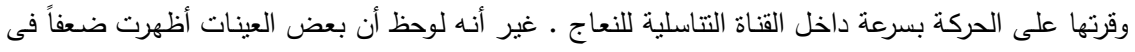

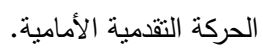

